ACTA THERIOLOGICA

Vol. 27, 13: 169-180, 1982

\title{
Non-metrical Divergence of Isolated Populations of Apodemus agrarius in Urban Areas
}

\author{
Michał D. SIKORSKI
}

Sikorski M. D., 1982: Nonmetrical divergence of isolated populations of Apodemus agrarius in urban areas. Acta theriol., 27, 13: 169-180 [With 3 Tables \& 2 Figs.].

Using frequency of 26 non-metrical skull variants as a basis, a comparative analysis was made of genetic differences in four populations of Apodemus agrarius (Pallas, 1771) inhabiting green spaces in Warsaw. It was found that $29(8.9 \%)$ out of 325 calculated coeffcients of correlation between variants significantly differed from zero. No signifcant correlations were found between frequency of occurrence of variants and body length. Tests were made of the homogeneity of occurrence of variants depending on the trapping area, age, sex and relevant seasonal generations. Lack of homogeneity of occurrence was found for seven variants, which were therefore omitted from further analysis, as was also one variant which failed to exhibit frequency differences in different populations. The mean measure of divergence was calculated for all pairs of compared populations from the frequency of occurrence of the remaining 18 variants, statistically significant differences being obtained in all cases. The results form evidence of genetic differentiation in the study populations of field mice.

[Mammals Res. Inst., Polish Acad. Sci., 17-230 Białowieża, Poland]

\section{INTRODUCTION}

Historical data on the fauna of urban areas justify the conclusion that the field mouse appeared in Warsaw about 60 years ago (Wałecki, 1881; Suminski, 1922), and at the present time the majority of urban green spaces in Warsaw are inhabited by this species (Babinska-Werka et al., 1979). These areas are situated in different zones of the city, from the suburban zone, in which contact is possible between the urban populations of field mice and the populations living in biotopes outside the city, to those situated in the centre of the city and completely surrounded by dense built-up areas, in which populations of this species may, to a great degree, be isolated. In addition field mouse populations living in different zones of the city are exposed to a different degree to the effects of urbanization factors.

Studies of field mice inhabiting different types of urban green spaces showed that the domination of this species in a rodent community increases with increase in the degree of urbanization of the biotope, while it is practically the only species present in the city centre. Differences were also found in structure, dynamics and certain intra- 
population processes (Andrzejewski et al., 1978), and also craniometric differences (Sikorski, 1982). Field mouse populations occupying urban green areas and adapting themselves to the conditions prevailing in such biotopes differ greatly from each other.

The specific conditions of the biotopes occupied by field mouse populations may, in addition to ecological and morphological differentiation, also lead to creation of genetic differences. Using genetic measures of divergence based on observed frequencies of the occurrence of nonmetrical variants, analysis was made of genetic differences between populations of field mice occupying urban green areas of Warsaw.

\section{STUDY AREA AND MATERIAL}

The studies carried out in Warsaw covered four types of urban green spaces. The first of these was the Eazienki Park together with the Botanic Garden, forming an area of about 50 ha covered by grass, with groups of old trees and bushes. It is situated near the city centre and surrounded on all sides by dense built-up areas and busy streets. The second study area was Bielany Grove, situated in the northern part of the city and about $7 \mathrm{~km}$ away from Eazienki Park. It is similar in character to a forest reserve and occupies an area of 130 ha, bounded both by dense built-up areas and by single dwelling houses, by busy streets and directly by the bank of the River Vistula. The third study area was Młociny Wood, lying at a distance of approx. $3 \mathrm{~km}$ from Bielany Grove in a northerly direction, and occupying an area of about 50 ha. It is surrounded on

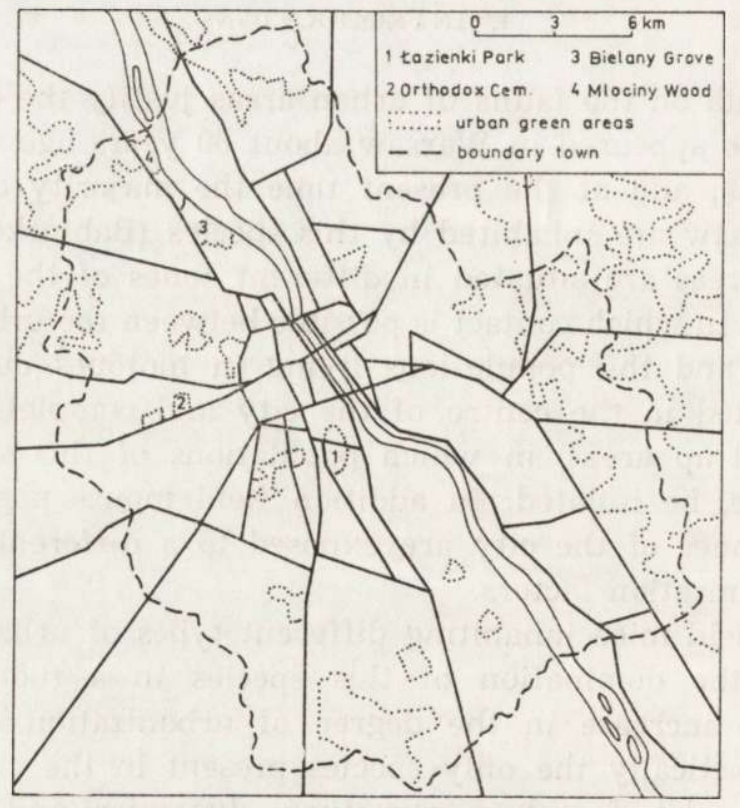

Fig. 1. Map of Warsaw. 
two sides by single dwelling houses and on the others by the bank of the Vistula and by a motor road forming the boundary between it and an extensive stretch of wooded land. The fourth study area is the Orthodox Cemetery lying to the west of a distance of about $7 \mathrm{~km}$ from Eazienki Park and Bielany Grove, and is covered by an old tree stand and dense herb layer. It is surrounded by busy streets and dense urban building (Fig. 1).

From 1975-1977 field mice were trapped every year in spring (May-June) and autumn (September-October), using live traps. The skulls were first cleaned by insects (Dermestes lardarius), then, in order to obtain a greater degree of cleanness, were digested in a papaine solution and blanched in $3 \%$ hydrogen peroxide. A total of 806 individuals were used for the studies (Table 1).

Table 1

Number of individuals classified with respect to all non-metrical skull variants.

\begin{tabular}{|c|c|c|c|c|c|c|c|c|c|}
\hline \multirow{3}{*}{$\frac{}{1975}$} & \multirow{8}{*}{$\begin{array}{r}\text { spring } \\
\text { autumn } \\
\text { spring } \\
\text { autumn } \\
\text { spring } \\
\text { autumn }\end{array}$} & \multicolumn{2}{|c|}{$\begin{array}{l}\text { Eazienki } \\
\text { Park } \\
\\
0\end{array}$} & \multicolumn{2}{|c|}{$\begin{array}{l}\text { Orthodox } \\
\text { Cemetery } \\
\text { of } \quad 0^{7} \sigma^{x}\end{array}$} & \multicolumn{2}{|c|}{$\begin{array}{c}\text { Bielany } \\
\text { Grove }\end{array}$} & \multicolumn{2}{|c|}{$\begin{array}{l}\text { Młociny } \\
\text { Wood } \\
\text { o } 0^{-1} 0^{\top}\end{array}$} \\
\hline & & 13 & 22 & - & - & 17 & 13 & 7 & \\
\hline & & 24 & 25 & - & - & 30 & 34 & 38 & 39 \\
\hline \multirow{2}{*}{1976} & & 31 & 46 & - & - & 24 & 34 & 20 & 24 \\
\hline & & 11 & 17 & - & - & 53 & 46 & 41 & 42 \\
\hline \multirow[t]{2}{*}{1977} & & 7 & 30 & 23 & 25 & - & - & - & - \\
\hline & & 6 & 22 & 16 & 17 & - & - & - & \\
\hline Total & & 92 & 162 & 39 & 42 & 124 & 127 & 106 & 114 \\
\hline
\end{tabular}

The whole of the material, in the form of conserved heads of field mice, was supplied by the Research Institute for Environment Development in Warsaw. A card index giving the following data was enclosed with the material: time and place of capture, body weight, standard body measurements and age of each individuals determined by means of the eye lens dry mass weight.

\section{STATISTICAL METHODS}

The fundamentai assumption in quantitative studies on frequency of non-metrical variants is to consider them as not correlated. Many of the non-metrical skeletal variants in mice are, however, probably genetically correlated due to the influence of common alleli. They are also correlated because they are affected by many of the same habitat factors. A condition for complete independence would thus be for the variants not to be affected by common alleli or by the same habitat factors. This condition is very limiting in relation to non-metrical variants, eacb of which probably does not occur completely independently of the others. For practical use therefore certain correlations between variants may be overlooked.

In order to reply to the question as to whether the degree of connection of variants significantly differs from the zero we accepted, after Sjøvold (1977), Pearson's coefficient of correlation expressed by the equation:

$$
\varphi=\frac{a d-b c}{\sqrt{(a+b)(a+c)(d+b)(c+d)}}
$$

where $a-$ is the number of individuals in which two variants occur simultaneously, $b-$ is the number of individuals having only one variant, $c$ - the number of 
individuals solely with the second variant and $d$ - the number of these individuals which have no variant.

In analyzing non-metrical variants it is necessary to reject variants which exhibit correlation with body size. These variants represent the same genome as metrical variants and the differences represented by them can be more exactly studied for instance by means of craniometric variations. For this purpose examination was made of the correlation between frequency of occurrence of variants and body length, and thus between variants of a quantitative and qualitative character. The degree of correlation was estimated by means of Pearson's coefficient of correlation accepted after Sjøvold (1977), which is expressed by the equation:

$$
r_{b}=\frac{\Sigma^{\prime} y-p \Sigma y}{u \sqrt{\mathrm{n} \Sigma y^{2}-(\Sigma y)^{2}}}
$$

where $\mathrm{n}-$ is the number of individuals possessing a variant, $p$ - is the relative frequency of occurrence of this variant, $\Sigma y$ and $\Sigma y^{2}$ are the sum totals of body length and square of body length, $\Sigma^{\prime} y$ is the sum total of the body lengths of individuals possessing a variant, $a-$ is the value of the function of probability density of the normal distribution. As body length in field mice exhibits sex dimorphism (Haitlinger, 1962; Adamczewska-Andrzejewska, 1973) calculation were made separately for females and males.

Homogeneity of occurrence of variations in samples from successive trapping years and seasons were tested by the chi-square test. Tests were also made of the homogeneity of occurrence of variants depending on age and the seasonal generation to which they belonged. The tests were made separately for the various study areas, and also for individuals from all years jointly, of the homogeneity of occurrence of variants in the two sexes. The statistical significance of differences in frequency of occurrence of variants in samples from the various study areas was calculated by means of the chi-square test, taking differences as significant with $p=0.05$, when inequality is fulfilled:

$$
\left(\Theta_{1}-\Theta_{2}\right)^{2}>3\left(\frac{1}{\mathrm{n}_{1}}+\frac{1}{\mathrm{n}_{2}}\right)
$$

In order to estimate genetic differences between the study populations the mean measure of divergence (MMD) was used, and is expressed between two populations by the equation:

$$
M M D=\frac{1}{r} \sum\left(\Theta_{1}-\Theta_{2}\right)^{2}-V
$$

where $r-$ is the number of variants examined, $\Theta-$ angular transformation in radians of relative frequency of variants $p-$ and is $\Theta=\arcsin (1-2 p)$. The expression $\mathrm{V}$ - is the correction making allowance for different sample size and is:

$$
V=\frac{1}{n_{1}+1 / 2}+\frac{1}{n_{2}+1 / s}
$$

where $\mathrm{n}-$ is the sample size. Statistical significance of differences between two populations may be tested by means of standard deviation of $M M D$, which is expressed by the equation: 


$$
\text { S.D. } M M D=\sqrt{\operatorname{var} M M D}=\sqrt{\frac{2}{\mathrm{r}} \mathrm{V}^{2}}
$$

The difference is statistically significant if the $M M D$ value is greater than the double value S.D.MMD.

\section{LIST OF NON-METRICAL VARIANTS}

The list of non-metrical variants contains, in addition to skull variants, the variable number of root alveoli of tooth $M^{1}$ and diversity of molar teeth. The classifying criteria for variants nos. 6, 7, 12, 19, 20, 22 and 23 were accepted after Berry \& Searle, 1963), variants nos. 10, 11, 14, 15, 18, 21 and 25 after Berry (1963), these papers also giving anatomical descriptions of these variants. Short anatomical descriptions are included for the remaining variants. Variants which may occur symmetrically or on one side only of the skull were taken to be present if they occurred symmetrically.

1. Four alveoli of $M^{1}$

2. Five alveoli of $M^{1}$

3. Six alveoli of $M^{1}$

4. Cingular cones $(\mathrm{co})$ of $M^{1}$ present. This is a small cone lying between the most mesial cone $(t 2)$ of the median row of nodes, and the mesio-labial cone ( $t 3)$ of $M^{1}$

5. Mesio-labial cone $(t 3)$ of $M^{2}$ present. Names of tooth cones taken from the paper by Misonne (1969)

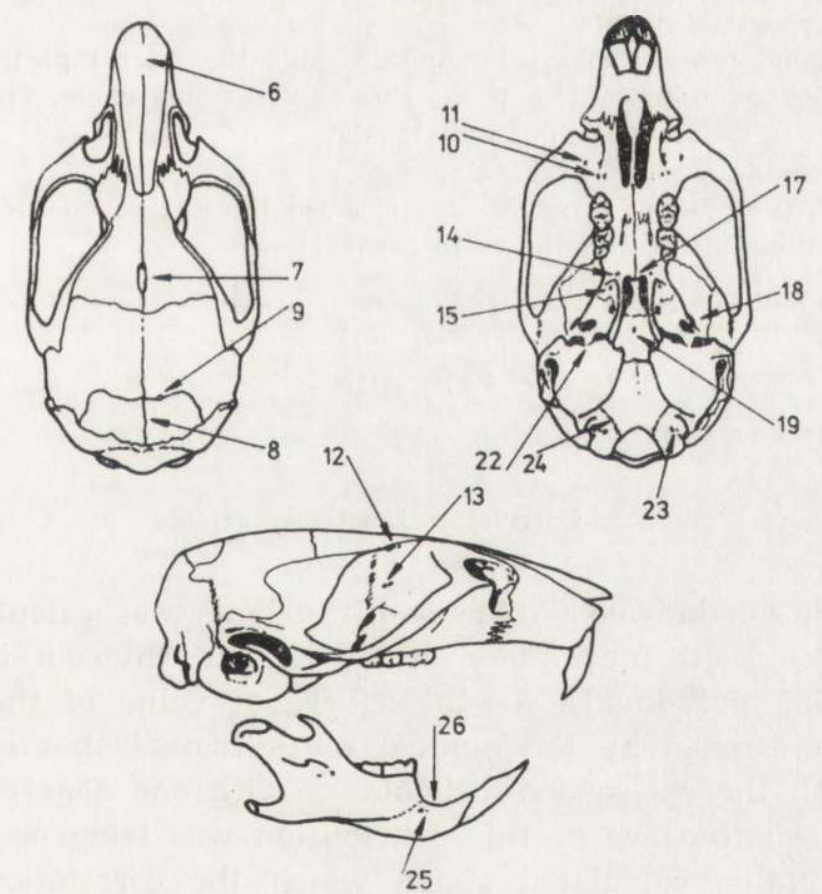

Fig. 2. Non-metrical variants in the skull of Apodemus agrarius. 
6. Nasals fused together

7. Parted frontals

8. Interparietal bones not fused. These are tegumental bones formed from paired rudiments, which very early combine in one plate. In sporadic cases they do not fuse but remain as paired bones.

9. Wormian bones present. These are small bones situated in the suture between the parietal and interparietal bones

10. Maxillary foramen I double

11. Maxillary foramen II present

12. Frontal foramen double

13. Ethmoid foramen double. This foramen is situated at the bottom of the eye socket on the frontal bone. It may be divided by a bony lamina into two foramina.

14. Foramen palatinum minus anterius present

15. Foramen palatinum minus posterius present

16. Postpalatal border curved into the palate

17. Postpalatal border bears a projection into the interpterygoid fossa. The posterior border of the bony palate formed by the subpalatal bones may be bent forwards in an arc or may have a bony thickening on the suture forming a bend in the opposite direction

18. Foramen ovale single

19. Foramen sphenoidale medium present

20. Foramen sphenoidale medium double

21. Foramen infra-ovale present

22. Processus pterygoideus present

23. Foramen hypoglossi double

24. Occipital bone not fused. Basiooccipitale joins the lateral parts at the back, and in older individuals these bones fuse to form one whole. They also occasionally remain unfused in older individuals

25. Accessory mental foramen present

26. Supra-dentary foramen present. This is a small foramen on the upper border of the mandible in front of the tooth row.

\section{RESULTS}

\subsection{Correlation Between Variants}

The correlation between all pairs of variants was calculated for the sample covering all four study areas, without division into sex, for a total of 806 individuals. As the square of value of the correlation coefficient multiplied by the number of individuals has a distribution agreeing with the chi-square distribution with one degree of freedom, the level of significance of this distribution was taken as $p=0.01$ and the critical value calculated above which the correlation coefficient differs significantly from zero; Out of 325 calculated correlation coeffi- 
cients between variants 29 , that is $8.9 \%$, differ significantly from zero. Variants nos. 17 and 19 exhibit the greatest number of significant correlation. with other variants, this being seven in both cases. The remaining variants exhibit a lower correlation number, while variants nos. 4, 5, 8, 18 and 22 are not correlated. It may therefore be taken that in general the degree of correlation between variants is low.

\subsection{Correlation Between Variants and Body Length}

The values of calculated correlation coefficients $r_{b}$ are very low. A maximum absolute values 0.2841 was found in males for variant no. 25 . Using the statistical test expressed by the equation:

$$
t_{0}=\frac{r}{\sqrt{1-r^{2}}} \sqrt{\mathrm{n}-2}
$$

where $\mathrm{n}$ - is sample size, $r$ - correlation coefficient.

The significance of differences of the correlation coefficient $r_{b}$ from zero was checked. On the level of significance of $p=0.05$ none of the coefficients differ from zero. Thus correlation of the selected variants with body length is not statistically significant in either sex.

\subsection{Homogeneity of Occurrence of Variants Depending on Time of Capture and Time of Birth (Generation)}

The homogeneity of occurrence of variants in successive trapping years was checked by means of the chi-square test on a level of significance $p=0.01$. In the three study areas (mice from the Orthodox Cemetery are from one year only, Table 1) variants nos. 17, 19 and 25 do not occur homogeneously. In addition lack of homogeneity of occurrence was found in Łazienki Park for variants nos. 12, 16 and 22, in Bielany Grove for variant nos. 1, 11 and 20 and in Młociny Wood for variants nos. 15 and 24. Differences in frequency of occurrence of variants in individuals caught in spring and autumn were found in three cases only in Eazienki Park for variant nos. 19 and 25 and in the Orthodox Cemetery for variant no. 21.

A similarly high homogeneity was found when comparing frequency of occurence of variants in the spring and autumn generations. Differences in frequencies of variants between generations were found in Łazienki Park for variants nos. 4 and 22 and in Bielany Grove for variants nos, 19 and 25 . 
As variants nos. 17,19 and 25 exhibit significant differences in frequency in all populations tested in successive trapping years they have been omitted in calculations of the measure of divergence. The above mentioned cases of statistically significant differences in frequency of variants in samples from successive trapping years and seasons and depending on the seasonal generation to which they belong were found only in single populations. These variants have not been omitted from further analysis.

\subsection{Homogeneity of Occurrence of Variants Depending on} Age and Sex

In oreder to eliminate variants, the frequency of occurrence of which depends on the age of the mice, a check was made of the homogeneity of occurrence of variants in four 2-month age classes. Variants nos. 12, $13,15,17$ and 24 in at least two of the study areas exhibit statistically significant differences in frequency of occurrence in different age classes. These variants, as being variants, of which frequency depends on the age of the individuals, have been omitted from further analysis.

Differences in the frequency of different variants between the two sexes are slight, being statistically significant on the level of significance of $p=0.05$ in Eazienki Park for variant nos 17 and 23, and in the Orthodox Cemetery for variants nos. 1, 10 and 25. Variants nos. 17 and 25 were rejected on the strength of results of the tests described in sections 5.3 and 5.4. Differences in frequency of the remaining variants occur only in single populations and were not omitted from further analysis on the basis of this test.

\subsection{Measure of Divergence Between the Study Populations}

Variants nos. 12, 13, 15, 17, 19, 24 and 25 were omitted from further analysis on the strength of results of tests for homogeneity of occurrence. Tests were next made for homogeneity of occurrence of the remaining 19 variants in individuals from different study areas. Significant differences in frequency (chi-square test) on the level of significance of $p=0.05$ was found for variants nos. $1,2,4,6,7,16,18,20,21$ and 23. On the basis of the test based on inequality (3) significant differences were found in the frequency of all variants except for variant no. 3, which has been omitted as not establishing a difference in $M M D$ calculations. Differences in frequency of variants were taken as significant, 
if they were found for at least one pair of study areas. The frequency in percentages for the remaining non-metrical variants is given in Table 2 .

Mean measures of divergence and standard deviations were calculated for all pairs of populations on the basis of the frequency of occurrence of 18 non-metrical variants (Table 3). It was found that MMD differences were statistically significant in all the pairs of populations compared. Values of the distinguishing measure have been given in Table 3 . The highest value of this parameter was found in the population inhabiting the Orthodox Cemetery, and thus this is the population rnost differing from the remainder.

Table 2

Percentage frequencies of non-metrical skull variants.

\begin{tabular}{lcccc}
\hline & $\begin{array}{c}\text { Eazienki } \\
\text { Park } \\
\mathrm{n}=254\end{array}$ & $\begin{array}{c}\text { Orthodox } \\
\text { Cemetery } \\
\mathrm{n}=81\end{array}$ & $\begin{array}{c}\text { Bielany } \\
\text { Grove } \\
\mathrm{n}=251\end{array}$ & $\begin{array}{c}\text { Młociny } \\
\text { Wood } \\
\mathrm{n}=220\end{array}$ \\
\hline 1. Four alveoli of $M^{1}$ & 42.1 & 58.0 & 54.6 & 37.7 \\
2. Five alveoli of $M^{1}$ & 24.0 & 9.9 & 16.7 & 30.5 \\
4. Cingular cones on $M^{1}$ present & 2.4 & 0 & 1.6 & 0 \\
5. $t$ 3 cone of $M^{2}$ present & 2.0 & 0 & 4.0 & 3.2 \\
6. Nasals fused together & 7.1 & 13.6 & 1.2 & 4.1 \\
7. Parted frontals & 3.5 & 1.2 & 0.8 & 1.4 \\
8. Interparietals not fused & 1.6 & 2.5 & 1.6 & 2.3 \\
9. Wormian bones present & 1.2 & 1.2 & 0.4 & 1.4 \\
10. Max. for. I double & 26.8 & 18.5 & 28.3 & 29.5 \\
11. Max. for. II present & 13.0 & 9.9 & 15.9 & 15.5 \\
14. For. palat. minus ant. present & 33.5 & 38.3 & 33.5 & 28.2 \\
16. Postpalatal border curved & 9.4 & 0 & 18.3 & 11.8 \\
18. For. ovale single & 2.4 & 1.2 & 3.2 & 9.1 \\
20. For. sphenoidale med. double & 4.3 & 7.4 & 8.8 & 7.7 \\
21. For. infra-ovale present & 52.0 & 46.9 & 37.1 & 41.4 \\
22. Proc. pterygoideus present & 23.6 & 32.1 & 24.3 & 23.6 \\
23. For. hypoglossi double & 7.5 & 16.0 & 24.7 & 10.9 \\
26. Supra-dentary for. present & 3.9 & 3.7 & 6.4 & 6.8 \\
\hline
\end{tabular}

\section{DISCUSSION}

The results obtained point to the genetic differentiation of the study populations of field mice. One of the factors affecting the genetic composition of the population is isolation, as the result of which there is limitation or complete elimination of migration. Goszczyński (1979), in examining the density of the field mouse population in the Orthodox Cemetery, found complete absence (not excluding a very low degree of intensity) of migration of individuals between the two parts of the Cemetery divided by a bank. He also ruled out the possibility of migration by these mice between the Orthodox Cemetery and the nearby park. Out of the four study populations it was in this one case 
only that direct proof was obtained of the isolation of the resident population. There is no direct proof of isolation in the case of the remaining three study areas. As shown by the description of the study areas, they are either directly bounded (Bielany Grove, Młociny Wood) or, like Łazienki Park, lie at no considerable distance from, the bank of the Vistula, which may be a beaver trail of animals' migration. Even so the probability of intensive migration consisting in constant interchange of individuals between populations inhabiting areas lying near the Vistula river bank is very slight. This points to statistically significant MMD differences (Table 3). These populations may therefore also be considered as markedly isolated.

Table 3

Mean measure of divergence $(M M D)$ and measure of uniqueness between study populatións. Standard deviations of $M M D$ s are given in italics.

\begin{tabular}{|c|c|c|c|c|}
\hline & $\begin{array}{l}\text { Orthodox } \\
\text { Cemetery }\end{array}$ & $\begin{array}{l}\text { Bielany } \\
\text { Grove }\end{array}$ & $\begin{array}{l}\text { Młociny } \\
\text { Wood }\end{array}$ & $\begin{array}{l}\text { Measures of } \\
\text { uniqueness }\end{array}$ \\
\hline Łazienki Park & $\begin{array}{l}0.0300 \\
0.0054\end{array}$ & $\begin{array}{l}0.0280 \\
0.0026\end{array}$ & $\begin{array}{l}0.0110 \\
0.0028\end{array}$ & 0.0690 \\
\hline Orthodox Cemetery & & $\begin{array}{l}0.0556 \\
0.0054\end{array}$ & $\begin{array}{l}0.0534 \\
0.0056\end{array}$ & 0.1390 \\
\hline Bielany Grove & & & $\begin{array}{l}0.0168 \\
0.0028\end{array}$ & 0.1004 \\
\hline Młociny Wood & & & & 0.0812 \\
\hline
\end{tabular}

An important factor which may have a significant influence on differentiation of populations in respect of their genetic composition is the time for which isolation persists. The field mouse was found for the first time as a new species in urban areas of Warsaw by Sumiński (1922). However, even if isolated populations had begun the process of differentiation at that time, the process most certainly underwent total interruption during the damage caused by hostilities during World War II. It was not until rebuilding started that conditions were formed for renewed differentiation of populations in different green areas. It may therefore be taken that limitation of migration leading to the present isolation of field mouse populations within Warsaw began about 30 years ago.

Berry \& Warwick (1974), in examining a population of Apodemus sylvaticus which became isolated over 100 years ago on Castle Rock in the centre of Edinburgh, did not find genetic differences between them and populations inhabiting areas outside the city. Even long-lasting isolation does not, therefore, necessarily lead to differentiation of a population.

The group of factors determining habitat conditions also affect dif- 
ferentiation of a population. Studies covering a very large number of urban green areas in Warsaw revealed considerable differences in the habitat conditions prevailing in them. A group of such conditions decides whether the areas are suitable for field mice (Babińska-Werka et al., 1979). The field mouse populations examined in the present study came from greatly differing areas, in which habitat conditions range from the almost natural ones in the Młociny Wood to the intensively urbanized conditions in Eazienki Park and the Orthodox Cemetery. Each of the four study populations occupies a widely differing position in the rodent community. The percentage of field mice in the community increases with increase in the urbanization influences in the biotope, and is far higher than the percentage of this species in the natural rodent community from the Kampinos Forest (Andrzejewski et al., 1978). It may be assumed from these data that intra- and interspecies competition takes a different form in the four study populations. The differing habitat conditions and different character of interspecies competition, through influence on the effects of natural selection lead, together with isolation, to differentiation of the genetic composition of field mouse populations in urban green areas in Warsaw.

Acknowledgements: The author wish to tender his thanks to Dr. R. Andrzejewski for making skull material available for these studies.

\section{REFERENCES}

1. Adamczewska-Andrzejewska K., 1973: Growth variation and age criteria in Apodemus agrarius (Pallas, 1771). Acta theriol., 18: 353-394.

2. Andrzejewski R., Babińska-Werka J., Gliwicz J. \& Goszczyński J., 1978: Synurbization processes in population of Apodemus agrarius. I. Characteristics of population in urbanization gradient. Acta theriol., 23: $341-358$.

3. Babińska-Werka J., Gliwicz J. \& Goszczyński J., 1979: Synurbization processes in a population of Apodemus agrarius. II. Habitats of the striped field mouse in town. Acta theriol., 24: 405-415.

4. Berry R. J., 1963: Epigenetic polymorphism in wild populations of Mus musculus. Genet. Res., 4: 193-220.

5. Berry R. J. \& Searle A. G., 1963: Epigenetic polymorphism of the rodent skeleton. Proc. zool. Soc. Lond., 140: 577-615.

6. Berry R. J. \& Warwick T., 1974: Field mice (Apodemus sylvaticus) on the Castle Rock, Edinburgh: an isolated population. J. Zool., Lond., 174: 325-331.

7. Goszczyński J., 1979: Density estimation for an urban population of field mouse. Acta theriol., 24: 417-419.

8. Haitlinger R., 1962: Morphological variability in Apodemus agrarius. Acta theriol., 6: 239-255.

9. Misonne X., 1969: African and Indo-Australian Muridae. Evolutionary trends. Ann. Mus. R. Afr. Cent., Sci. Zool., 172: 1-219. 
10. Sikorski M. D., 1982: Craniometric variation of Apodemus agrarius (Pallas, 1771) in urban green areas. Acta theriol., 27: 71-81.

11. Sjøvold T., 1977: Non-metrical divergence between skeletal populations. Ossa, 4: supplement 1: $1-133$.

12. Sumiński S. M., 1922: Fauna Warszawy. Ziemia, 7, 12: 328-335.

13. Wałecki A., 1881: Fauna zwierząt ssących Warszawy i jej stosunek do fauny całego kraju. Pam. fizjograf., 1: 226-291.

Accepted, April 6, 1982.

Michał D. SIKORSKI

\section{NIEMETRYCZNE ZROZNICOWANIE IZOLOWANYCH POPULACJI APODEMUS AGRARIUS NA TERENACH MIEJSKICH}

\section{Streszczenie}

Analizę częstości występowania 26-ciu cech niemetrycznych przeprowadzono na 806 czaszkach myszy polnej odłowionej na terenie Warszawy w Parku Łazienkowskim wraz z Ogrodem Botanicznym, Lesie Bielańskim, Lesie w Młocinach i na Cmentarzu Prawosławnym. Stwierdzono niską korelację pomiędzy cechami oraz pomiędzy częstością występowania cech a długością ciała myszy. Różnice frekwencji cech w zależności od przynależności do generacji sezonowych i płci były niewielkie. Stwierdzono natomiast istotne różnice frekwencji cech $\mathrm{nr} 17,19$ i $25 \mathrm{w}$ kolejnych latach odłowów. Istotne różnice frekwencji w zależności od wieku myszy wykazują cechy $\mathrm{nr} 12,13,15,17$ i 24 . Cechy te zostały pominięte w obliczeniach średniej miary dywergencji $(M M D)$. Pominięto również cechę $\mathrm{nr} 3$, która nie wykazywała różnic frekwencji w poszczególnych populacjach. Na pođstawie częstości występowania 18-stu niemetrycznych cech obliczono średnie miary dywergencji, które posłużyły do oceny różnic genetycznych między populacjami. We wszystkich przypadkach MMD okazały się statystycznie istotne (Tabela 3), co świadczy o zróżnicowaniu genetycznym czterech populacji myszy polnych z terenów zieleni miejskiej Warszawy.

Za przyczynę zróżnicowania genetycznego badanych populacji myszy polnych uznano izolację populacji, zróżnicowane warunki zajmowanych siedlisk oraz odmienny charakter konkurencji wewnątrz- i międzygatunkowej. 